\title{
Nódulo doloroso en región parietal
}

\author{
Hernández Guilabert PM ${ }^{\mathrm{a}}{ }^{1}$, Hernández Sánchez G. ${ }^{2}$
}

Sanid. mil. 2013; 69 (3): 213-214; ISSN: 1887-8571

Paciente de sexo femenino, fumadora, y sin otros antecedentes de interés, que consulta por nódulo doloroso en región parietal derecha de dos meses de evolución sin otra sintomatología acompañante. La exploración clínica no evidencia otras lesiones ni anomalías morfológicas ni funcionales. Se indica la realización de un TAC craneal.

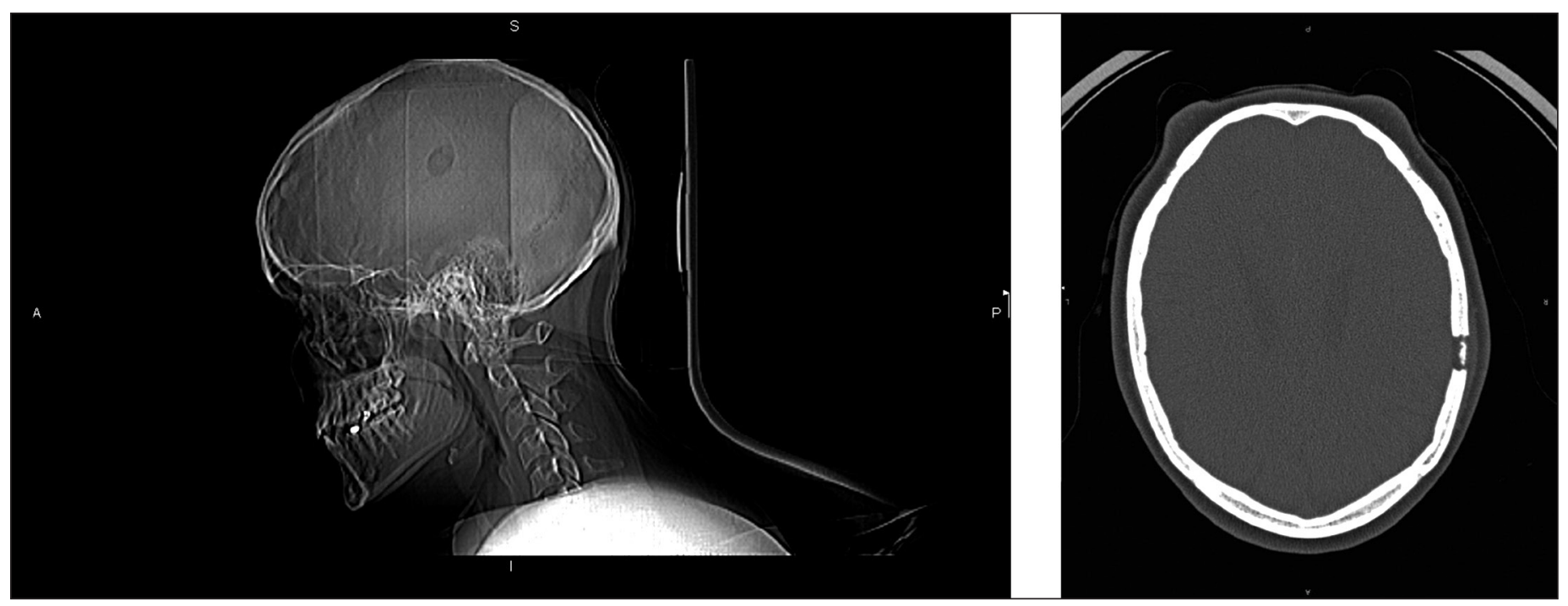

Figuras 1 y 2. TAC de cráneo: Lesión osteolítica en el hueso parietal derecho, interesando ambas tablas, con un secuestro óseo de localización central.

Ante los hallazgos del TAC craneal, se indica la realización de un TAC de alta resolución de tórax.

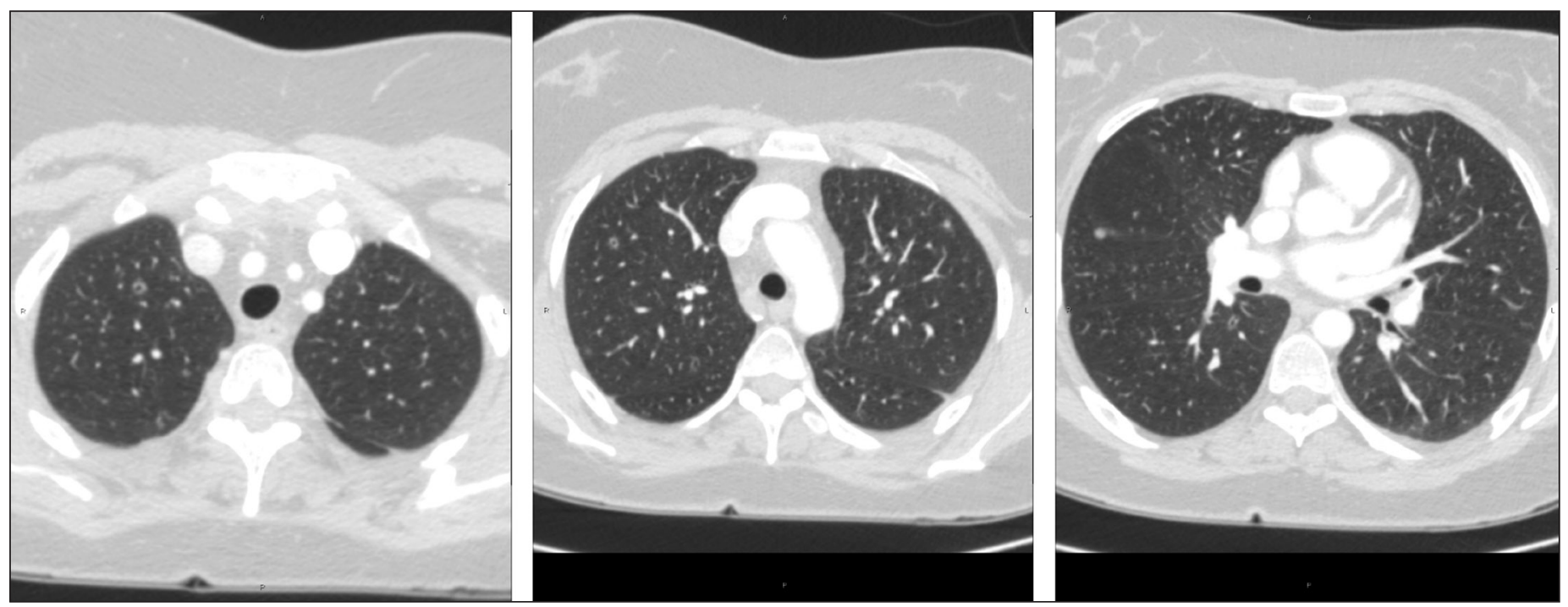

Figuras 3, 4 y 5. TAC de tórax: Lesiones nodulares múltiples de dimensiones milimétricas, predominando en lóbulos superiores, algunas de ellas con cavitación.

\footnotetext{
${ }^{1}$ Médico Interno Residente. Complejo Hospitalario de Toledo. Servicio Radiología. España.

${ }^{2}$ Col. Médico. Hospital Central de la Defensa Gómez Ulla. Servicio Radiología. Madrid. España.

Dirección para correspondencia: Dr. Gonzalo Hernández. Servicio Radiología. Hospital Central de la Defensa Gómez Ulla. Glorieta del Ejército 1. 28047 Madrid.

Recibido: 20 de mayo de 2013

Aceptado: 14 de junio de 2013
} 


\section{Diagnóstico: Histiocitosis de células de Langherhans}

El TAC craneal demostró una lesión osteolítica parietal derecha, con un secuestro óseo y pequeña masa de partes blandas asociada. Considerando la edad de la paciente, se plantearon los diagnósticos, por orden de probabilidad, de granuloma eosinófilo, epidermoide, dermoide y hemangioma.

El TAC de tórax demostró varias formaciones nodulares de pequeño tamaño dispersas en el parénquima pulmonar, pero predominando en campos superiores, algunas de ellas con cavitación. Estos hallazgos reforzaron la sospecha de granuloma eosinófilo.

La paciente fue intervenida de la lesión craneal. El diagnóstico anatomopatológico fue de granuloma eosinófilo.

Posteriormente se pauto un tratamiento corticoideo, observándose en controles posteriores la desaparición prácticamente completa de las lesiones pulmonares.

\section{DISCUSIÓN}

La histiocitosis X o histiocitosis de células de Langerhans incluye enfermedades que difieren tanto en su clínica como en la edad de presentación, aunque comparten un sustrato morfológico común, la proliferación histiocítica. Estas enfermedades son el granuloma eosinófilo, la enfermedad de Letterer-Siwe y la enfermedad de Hand-Schüller-Christian.
El granuloma eosinófilo afecta sobre todo a los adultos y puede ser focal o multifocal. La enfermedad de Hand-SchüllerChristian consiste en la triada de lesiones craneanas osteolíticas, diabetes insípida y exoftalmía. La enfermedad de Letterer-Siwe ocurre en lactantes y niños, presenta afección multiorgánica y su curso es fatal.

El granuloma eosinófilo afecta al sistema óseo en un 4-20\% de los casos, aunque es el pulmón el principal órgano implicado.

Los huesos más afectados son mandíbula, cráneo, costillas y fémur ${ }^{1}$. Se aprecian imágenes osteolíticas bien delimitadas, que clínicamente pueden ser asíntomáticas u ocasionar dolor, tumefacción, impotencia funcional o fracturas patológicas.

La afectación pulmonar se manifiesta en forma de nódulos pequeños predominando en lóbulos superiores y medio, evolucionando hacia un patrón reticular y en panal con formación de quistes $^{2}$.

\section{BIBLIOGRAFIA}

1. Vandeurzen K, Delanote M, Verschakelen J, Sciot R, Decramer M. Pulmonary histiocytosis X diagnosed by bone biopsy. Report of a case. Acta Clin Belg 1994; 49: 99-103.

2. Kulwiec EL, Linch DA, Aguayo SM, Schwarz MI, King TE. Imaging of pulmonary histiocytosis X. Radiographics 1992; 12: 515-526 